\title{
Chile: is the fee for non-use of water rights effective?
}

\section{Christian Valenzuela, Rodrigo Fuster and Alejandro León}

ABSTRACT

Christian Valenzuela is a Researcher at the Territorial Analysis Laboratory (LAT) of the University of Chile. cvalenzuela@renare.uchile.cl

Rodrigo Fuster is a Professor at the Department of Environmental Sciences and Renewable Natural Resources (DCA \& RNR) of the University of Chile.rfuster@uchile.cl

Alejandro León is a Professor at the Department of Environmental Sciences and Renewable Natural Resources (DCA \& RNR) of the University of Chile. aleon@renare.uchile.cl 


\section{I}

\section{Introduction}

The Water Code enacted in Chile in 1981 allowed the State to grant water rights to private users free of charge ${ }^{1}$ and in perpetuity, with no obligation to justify the flow applied for, state the field of production involved or actually use the rights. The result was that a substantial proportion of these rights were left unused and unavailable for projects that might have made effective use of them, once water rights to the source concerned had been fully allocated for the purposes of law. In 2005, the Code was reformed with the introduction of a non-use fee to discourage certain market agents from accumulating rights. ${ }^{2}$ Now in 2011, with four fee charging rounds completed and a fifth in progress, this study sets out to determine whether the fee has effectively discouraged ownership of rights without effective use, by analysing the results of its implementation.

International practice is for water rights to be made conditional on specific uses, since granting rights for effective and beneficial uses prevents speculation and the creation of monopolies, as indicated, for example, by United States law (ECLAC, 1995). No provision was made for this in the Chilean legislation, and "the decision not to make rights conditional upon effective and beneficial uses or to adopt alternative measures has encouraged speculation and hoarding, facilitating the manipulation of water rights as an instrument of unfair economic competition, and meant that they can be used to exercise market power" (Dourojeanni and Jouravlev, 1999). In comparative law, charging a fee for water rights, as is currently done in Chile, is unusual in that it entails an approach radically different to the "charging for use (or possession) of water" that predominates both in developed countries (Barde and Braathen, 2002) and in developing ones (Jouravlev, 2000) where charges exist. Thus, the Chilean non-use fee is an exception to the rule that charges apply to natural (untreated and non-potable) continental waters, making it an interesting subject for analysis.

\footnotetext{
1 The exception are the auctions carried out by the State authority in situations where two or more applications cannot be met from the water available for the creation of new water rights, in which case payment does take place.

2 Rights awarded before 1981 were (theoretically) in use, since the merced de agua, as water rights were called before that year, only became definitive once water extraction facilities were in place (Peña, 2003).
}

While speculators usually look to profit under conditions of uncertainty, the situation was different in Chile's water markets, since having water rights without effective use entailed no risk whatsoever given that:

(i) until 2006, owners were not obliged to invest in facilities $^{3}$ to make effective use of their rights;

(ii) many of the water rights used for speculation were granted free of charge by the State; and

(iii) even if speculation took place with rights purchased in the marketplace, the risk remained close to zero as demand has grown steadily and the prices of water rights have shown a steady upward trend (Dourojeanni and Jouravlev, 1999).

These arguments meant that the opportunity cost of keeping rights unused or unsold was less than the profits from rising prices (Dourojeanni and Jouravlev, 1999). The result was a situation that was strategically problematic for the country, considering that water is a vital natural resource and an irreplaceable production input.

Consequently, in 1992 the Government of Chile decided on a core amendment to the Water Code requiring unused water rights to be surrendered, which meant that they would lapse after a period of non-use (Aylwin, 1992). However, this amendment, entailing the application of a command and control type instrument, did not enjoy a consensus among users or in Parliament; indeed, "there was a major debate within the Government" (Lagos, cited by Comisión Especial sobre Régimen Jurídico de las Aguas, 1997). The outcome was that the idea of charging for unused rights was implemented (Comisión Especial sobre Régimen Jurídico de las Aguas, 1997), although it took 13 years of parliamentary debate for agreement to be reached on the application of this economic instrument.

The diagnosis by the executive branch found that there were about 50,000 cubic metres per second $\left(\mathrm{m}^{3} / \mathrm{s}\right)$ in outstanding applications to the State from hydroelectric companies for non-consumptive water

\footnotetext{
3 These are extraction facilities in the case of consumptive water rights and extraction and return facilities in the case of non-consumptive water rights. Chilean water law distinguishes between consumptive and non-consumptive rights. The former are defined as those that entitle their owner to fully consume the water concerned in any activity, while the latter are defined as those that allow water to be used but not consumed, with a requirement to return it in the manner determined when the right is acquired or constituted (Ministry of Justice, 1981).
} 
rights, which if granted would prevent rights from being constituted for a range of other uses and would consequently hinder economic development. In 1996, the Department of Water (DGA) of the Ministry of Public Works (MOP) estimated that the country's effectively usable hydroelectric resources (nonconsumptive water rights) from the Aysén Region to the north totalled no more than about $30,000 \mathrm{~m}^{3} / \mathrm{s}$. At that time, non-consumptive rights in current use represented a total flow of $1,699 \mathrm{~m}^{3} / \mathrm{s}(5.7 \%$ of the estimated effectively usable total), while constituted but unused rights represented 11,203 m³ $/ \mathrm{s}$ (37.3\%) and rights applied for and pending approval totalled 38,509 $\mathrm{m}^{3} / \mathrm{s}$ (128\%), with most being accounted for by just one hydroelectric company (Comisión Especial sobre Régimen Jurídico de las Aguas, 1997). The potential for monopolization, for control of hydroelectric generation and for closure of basins to other uses was obvious (Comisión Preventiva Central, 1996). At that time, the Central Preventive Commission (Comisión Preventiva Central, 1996) advised the Department of Water not to approve any new non-consumptive rights pending implementation of a legal amendment designed to ensure proper water usage, unless the projects concerned were of general interest.

The charge was thus designed as an annual fee, payable to the State, on the proportion of flows left unused because the owners of the rights had not constructed the necessary facilities. If the fee was not paid, the water right would be put up for auction. It was established that fee revenues (whether from payment or from auctions for non-payment) would be divided between the National Fund for Regional Development of the regional government concerned $(65 \%)$, municipalities in proportion to the surface area of their communes intersecting with the basin and the registration area concerned (10\%) and the general central Government treasury $(25 \%)$.

At the same time, the reform made provision for a number of exceptional situations in which rights are exempted from payment of the non-use fee even in the absence of facilities, ${ }^{4}$ these situations having been included for the "peace of mind" of those who viewed the reform as threatening (Peña, 2009). The Act also established that, once the necessary facilities had been built, the owner would be reimbursed (via tax deduction) for up to the last six non-use fee payments in the case of consumptive rights and up to the last eight in that of non-consumptive rights (MOP, 2005).

Thus, the goals in establishing the non-use fee for water rights were (Riestra, 2009a):

(i) to keep water available for those who needed it and had plans for it, encourage rational use and do away with hoarding and speculation so as to favour competition;

(ii) to constitute water rights for flows that were actually in use; and

(iii) to redistribute rights that were not in use.

Given the goals detailed above, the optimum take from the non-use fee is nil (Pérez, cited in Comisión de Hacienda del Senado, 2004), i.e., a situation in which all owners are making use of their water rights.

Following this Introduction, the present study is organized as follows: section II contains the methodology and the data collected for the research, section III expounds and discusses the empirical results, and section IV offers conclusions.

\footnotetext{
4 These exceptional situations are provided for in article 129 bis 4 , point 4; 129 bis 5, fifth paragraph; 129 bis 6, second, third and fourth paragraphs; and 129 bis 9 of Act No. 20017 (MOP, 2005).
}

\section{II}

\section{Methodology and data}

One mechanism for measuring the effectiveness of the non-use fee is to compare the amount charged with the actual take from it. The closer the take is to zero, the more successful the fee is being, as water rights with fee arrears are auctioned by the State and acquired by new owners. Conversely, the closer the take is to the amount charged, the less successful the non-use fee is being, as paying the fee allows owners to retain rights without effective use.

Another mechanism for measuring the effectiveness of the fee is to contrast the market price of rights with the non-use fee amount, since a pure speculator who 
owned water rights could select the most profitable (or least costly) option: using or selling the water rights, or paying the fee while waiting to transfer the rights at the best possible price.

Given the above, and to determine how effective the non-use fee has been in its purpose of discouraging ownership of rights without effective use, a descriptive analysis was carried out by way of two comparisons.

\section{Fees charged and paid}

This first comparison was carried out for the charging rounds from 2007 (the first year the non-use fee was charged) to $2009^{5}$ at the region and macrozone level for the whole of Chile, distinguishing between consumptive and non-consumptive water rights. Three macrozones were established, coinciding with the geographical breakdown of the non-use fee levied for consumptive rights ${ }^{6}$ (see figure 1). Fees were also linked to the number of rights and the flows of water involved. Data were taken from the official listing of water rights liable to payment of a non-use fee and databases showing the take ${ }^{7}$ from fees on the rights listed (DGA, 2010a). This was complemented by reviewing the 2010 charging round to analyse the number of rights owners leaving and remaining on the list of rights liable to the 30 largest fee payments, for both consumptive and non-consumptive water rights, on the assumption that there is a particularly strong incentive for this group of rights to start being used.

The following criteria were then used to gauge the effectiveness of the non-use fee:

(i) "Percentage of fees charged that are actually paid and number of rights and water flow liable" (criterion A). This percentage is inversely proportional to the likelihood of rights being redistributed, since the closer it is to $100 \%$, the greater the preference it reveals on the part of owners for paying the non-use fee and keeping rights unused instead of employing or selling them or waiting for the State auction.

\footnotetext{
5 At the time this study was carried out, the 2010 non-use fee charging round was under way, while the 2011 round had yet to begin, which is why these two rounds were not included in this first part of the analysis.

6 Although the geographical breakdown of charges for the non-use fee on non-consumptive rights is different, the data were tabulated for both types of rights with the breakdown described to facilitate comparison.

7 The list includes partial fee payments in very isolated cases, representing a percentage close to zero of the total fee take. For the purposes of the analysis, only fees paid in full were considered, as rights with partial payments are meant to go to auction for non-payment.
}

(ii) "Differences in the fees charged and in the number of rights and water flow liable for them between successive charging rounds" (criterion B). In other words, if in any given year the list contains fewer rights liable to the fee (or fewer fees charged or a smaller chargeable flow) than the year before, this means that water rights have come off the payment list because they have started to be used, so that the purpose of the non-use fee has been met. If the opposite happens, i.e., if in a given year there are more rights on the list (or more fees charged or a greater chargeable flow) than the year before, this will be because new rights have been incorporated into the oversight process, and not necessarily because no rights have come off the list. Consequently, no precise conclusions can be drawn from this situation.

\section{The market price of rights relative to the fee}

This second comparison was carried out separately for consumptive and non-consumptive water rights. For the former, the comparison was carried out on a regional scale for the whole of Chile, while for the latter it was carried out case by case, owing to the scarcity of data.

The comparisons only covered transactions from 2005, when the non-use fee came into force, until 2009, the latest year with information available for this study. The transaction data were obtained from the records of property registries (DGA, 2009), the auction section of the Department of Water website (DGA, 2010b) and a private business, Remates Fernando Zañartu Rozas y Cía. Ltda. (Gallo, 2010).

For consumptive rights, average regional market prices per 50 litres per second $(1 / \mathrm{s})$ of permanent and continuous use were estimated. ${ }^{8}$ The estimation was carried out on a regional scale because the bulk of the data, obtained from the Department of Water (DGA, 2009), were not suitable for compiling a list at the basin or aquifer level, these being the geographical units in which water markets operate. ${ }^{9}$

In the case of non-consumptive rights, use was made of all available market transaction records that provided

\footnotetext{
8 As well as being classified as consumptive and non-consumptive, water rights may be exercised permanently or contingently, and may be continuous or discontinuous or alternate between different users. Details of this typology can be found in articles 16 to 19 of legislative decree 1122, which fixes the text of the Water Code (Ministry of Justice, 1981).

9 In Chile, the boundaries of political and administrative regions coincide only sometimes with basins and never with aquifers.
} 
FIGURE 1

\section{Regions of Chile and macrozones for applying the non-use fee} to consumptive water rights

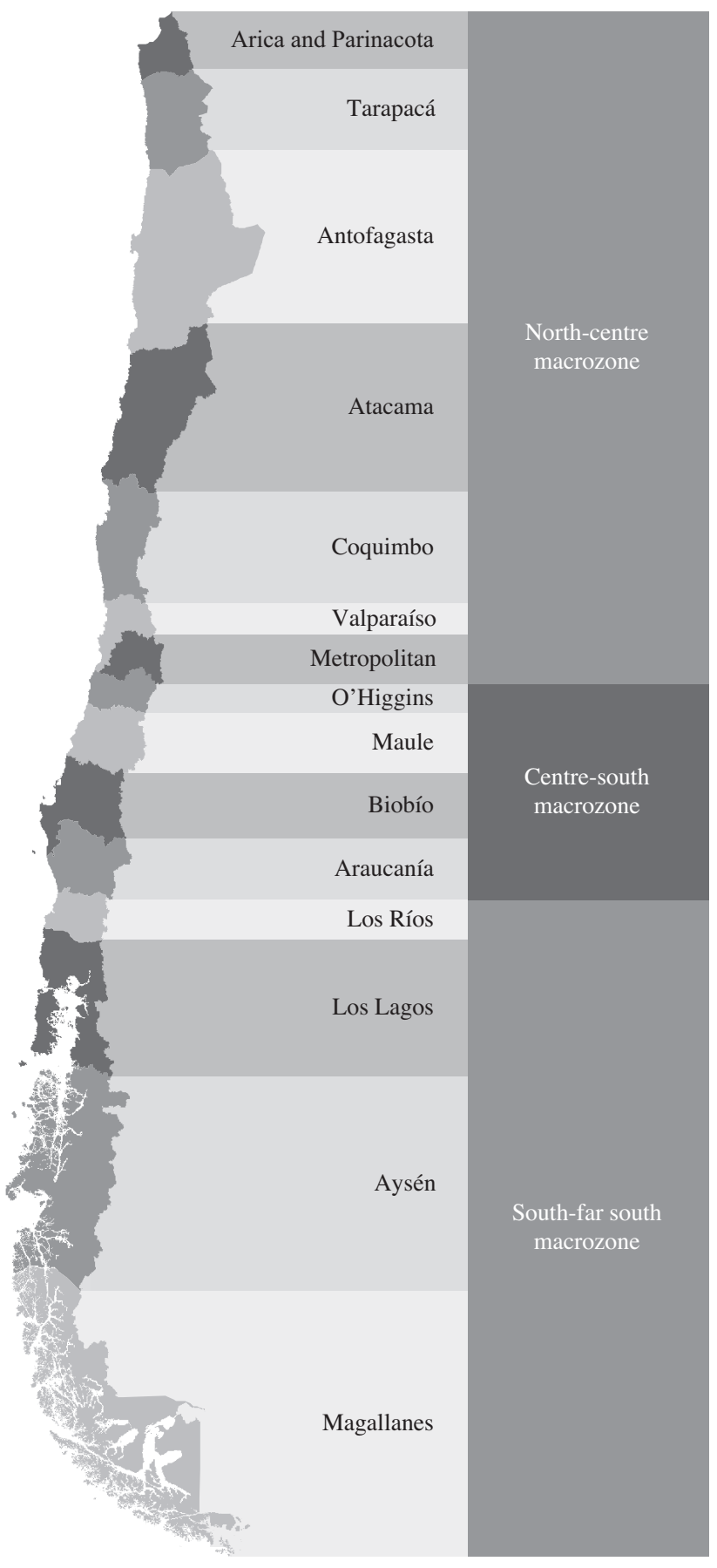

Source: prepared by the authors. 
enough detail for the fee to be calculated ${ }^{10}$ and caseby-case comparisons made. This procedure is justified because non-consumptive water rights transactions:

(i) are few in number compared with consumptive water rights transactions, and little in the way of data is available on them;

(ii) mainly take place between the Maule and Los Lagos regions;

(iii) cannot be averaged out, since one variable they include is the height difference between the extraction and return points, which is important to the price because it affects hydroelectric power; and

(iv) are less influenced in their pricing by latitude and climate variability (a consequence of Chile's geographical distribution) than are consumptive water rights transactions, with local variables having a greater influence on the value of each litre per second, such as proximity to the power distribution system or the geological conditions of the flow, which affect the type of hydroelectric installation used. ${ }^{11}$

Act. No. 20017 amending the 1981 Water Code (MOP, 2005) yielded equations (1) and (2), which calculate the non-use fee to be paid for consumptive and non-consumptive rights, respectively:

$$
\begin{gathered}
F_{\mathrm{C}}=\gamma_{\mathrm{C}} \cdot Q_{\mathrm{C}} \cdot f \\
F_{\mathrm{NC}}=\gamma_{\mathrm{NC}} \cdot Q_{\mathrm{NC}} \cdot H \cdot f
\end{gathered}
$$

where:

$F_{\mathrm{C}}$ : fee for consumptive water rights in monthly tax units (UTM). ${ }^{12}$

$F_{\mathrm{NC}}$ : fee for non-consumptive water rights in UTM.

10 Most of the few records available on non-consumptive rights transactions fail to report the height difference between the water extraction and return points, or the geographical coordinates of these points, from which it would be possible to ascertain the altitude and estimate the height difference, a variable that needs to be known for the fee to be calculated.

11 No information is available on other non-consumptive uses, such as fish farming or industrial refrigeration, as they amount to only a tiny fraction of hydroelectricity use.

12 Monthly tax unit: a unit of account, adjusted monthly for inflation, that is used in Chile for tax purposes and fines.
$\gamma_{\mathrm{C}}:$ macrozonal constant for consumptive water rights (north-centre 1.6; centre-south 0.2; south-far south 0.1 ).

$\gamma_{\mathrm{NC}}$ : macrozonal constant for non-consumptive water rights $(0.33$ from Chiloé northward and 0.22 from Palena southward, these both being provinces in the Los Lagos Region).

$Q_{\mathrm{C}}$ : mean unused flow for consumptive water rights (in litres per second).

$Q_{\mathrm{NC}}$ : mean unused flow for non-consumptive water rights (in cubic metres per second).

$H$ : height difference between the extraction and return points (in metres). ${ }^{13}$

$f$ : $\quad$ progressiveness factor ( 1 from the first to the fifth year of charging, 2 from the sixth to the tenth and 4 from the eleventh onward).

Both equations are designed for permanently and continuously exercised rights. Notwithstanding this, the design of the fee establishes the following:

(i) Contingent rights are liable to one third of the fee payable for an equivalent permanently exercised right.

(ii) For rights with differentiated flow distribution over the year, the annual average is taken.

(iii) For discontinuously exercised rights, any months with a positive flow are added together and the result is divided by 12 .

(iv) No difference is made between fees for surface water and groundwater.

(v) Provisional rights are also liable to fee payment.

Lastly, the effectiveness of the non-use fee was determined using the criterion "Difference between the non-use fee charged and the market price of a right" (criterion C); the larger this gap is, with the market price representing the upper bound, the greater the likelihood of owners paying the fee and retaining their unused rights. Conversely, the smaller this gap (and whenever the market price is the lower bound), the smaller the likelihood of owners choosing to retain their unused rights.

\footnotetext{
13 This variable cannot be less than $10 \mathrm{~m}$, so this value is used for smaller height differences.
} 


\section{III}

\section{Empirical findings and discussion}

\section{Fees charged and paid}

The payment percentage rose over the successive fee charging rounds, from $67 \%$ of the fee amount charged in 2007 to $81.4 \%$ in 2009 . Nonetheless, the percentage of all rights on which the fee was paid fell from $63.4 \%$ in 2007 to $50.9 \%$ in 2009 (see table 1). This situation arose because:

(i) some rights have been surrendered, ${ }^{14}$ some have been redistributed to new owners and some unused rights have started to be used;

(ii) the highest fees for non-consumptive water rights have usually continued to be paid; and

(iii) in the 2008 and 2009 charging rounds, new rights liable to lower fees (colloquially known as "smaller rights") were incorporated into the list, the result being a progressive drop in the average fee per chargeable right and a low level of variability in the average fee per right charged for (see table 1). Again, the value of fees charged was US\$2,943,626 less in 2009 than in 2008 (see table 1), a figure that reflects the removal of a number of rights from the list because they were surrendered, sold or brought into use. For this group of water rights, in other words, the

14 Surrender of water rights was provided for in Act No. 20017 and, as the name indicates, it consists in a person surrendering ownership of a right. When this happens, the right is extinguished and the water associated with it becomes available; non-payment of the non-use fee creates a different situation, as then the water right is auctioned off. non-use fee succeeded in its purpose, except in the case of rights that came off the list because their owners found a way of avoiding the fee, as will be discussed further on.

A more specific breakdown of the data (see figure 2) reveals that the fee total charged for consumptive rights was similar in 2007 and 2008, before diminishing in 2009, while in the case of non-consumptive rights the opposite happened, even as the number of rights liable for the fee, both consumptive and non-consumptive, increased (see figure 3). Regarding the proportion of fees actually paid, this has always exceeded $95 \%$ in the case of nonconsumptive rights, whereas payment of consumptive rights did not reach $50 \%$ until 2009. This indicates at least that the non-use fee is proving successful for consumptive water rights, while the data available do not yet allow a trend to be established for non-consumptive rights.

Similarly, consumptive water rights have been exiting the list of rights liable to the highest fees (see table 2), but this is not so with non-consumptive rights, which tend to crop up in the list year after year (see table 3 ). This can be corroborated by examining the ranking for 2010 (the last column of tables 2 and 3), since only 2 out of 30 consumptive rights are listed for earlier rounds, while a further 2 did come up in earlier rounds but under different ownership, meaning that they were sold or transferred and will presumably soon begin to be used. Conversely, only three non-consumptive rights appeared in the list for the first time in the 2010 round, and just two exited the list that year. The rest were rights that had previously been in the list, either as the

TABLE 1

Non-use fees charged and paid, national total, 2007-2009

\begin{tabular}{|c|c|c|c|c|c|c|c|c|}
\hline \multirow{2}{*}{$\begin{array}{l}\text { Charging } \\
\text { round }\end{array}$} & \multicolumn{3}{|c|}{$\begin{array}{l}\text { Fees } \\
\text { (dollars) }\end{array}$} & \multicolumn{3}{|c|}{$\begin{array}{l}\text { Number of rights } \\
\text { (units) }\end{array}$} & \multicolumn{2}{|c|}{$\begin{array}{c}\text { Average fee per right } \\
\text { (dollars) }\end{array}$} \\
\hline & Charged & Paid & Percentage & Liable & Paid & Percentage & Liable & Paid \\
\hline 2007 & 25349632 & 16971827 & 67.0 & 1302 & 826 & 63.4 & 19470 & 20547 \\
\hline 2008 & 28767544 & 21097355 & 73.3 & 1554 & 959 & 61.7 & 18512 & 21999 \\
\hline 2009 & 25823918 & 21017428 & 81.4 & 2006 & 1021 & 50.9 & 12873 & 20585 \\
\hline
\end{tabular}

Source: prepared by the authors on the basis of Department of Water (DGA), Bases de datos del listado de derechos de aprovechamiento de aguas afectos a pago de patente por no uso, procesos 2007 a 2010, Santiago, Chile, Ministry of Public Works (MOP), 2010. 
property of a single owner or as the property of two or even three different owners. An example can be found in the fourth, fifth and sixth records of table 3 , with the owner changing over the years ("Beatriz Cortés Torres" in 2007 and 2008, "Inversiones Arlequín Ltda." in 2009 and "Hidroeléctrica Centinela Ltda." in 2010), indicating that the same right had been kept unused for four years by different owners.

FIGURE 2

Revenues from non-use fees charged and paid, 2007-2009

(Millions of dollars)

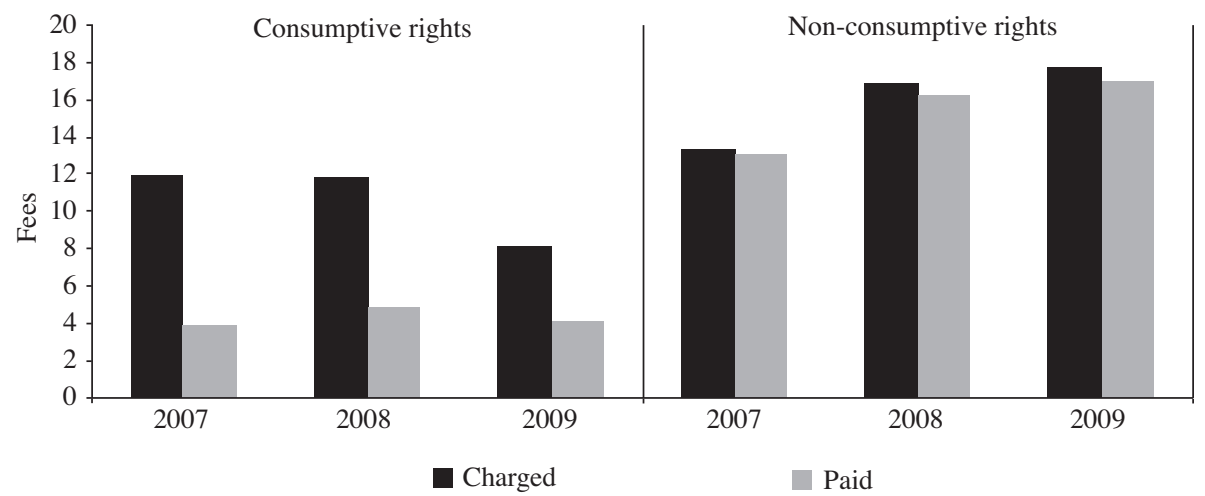

Source: prepared by the authors on the basis of Department of Water (DGA), Bases de datos del listado de derechos de aprovechamiento de aguas afectos a pago de patente por no uso, procesos 2007 a 2010, Santiago, Chile, Ministry of Public Works (MOP), 2010.

FIGURE 3

Number of rights liable to non-use fees and number paying, 2007-2009

(Units)

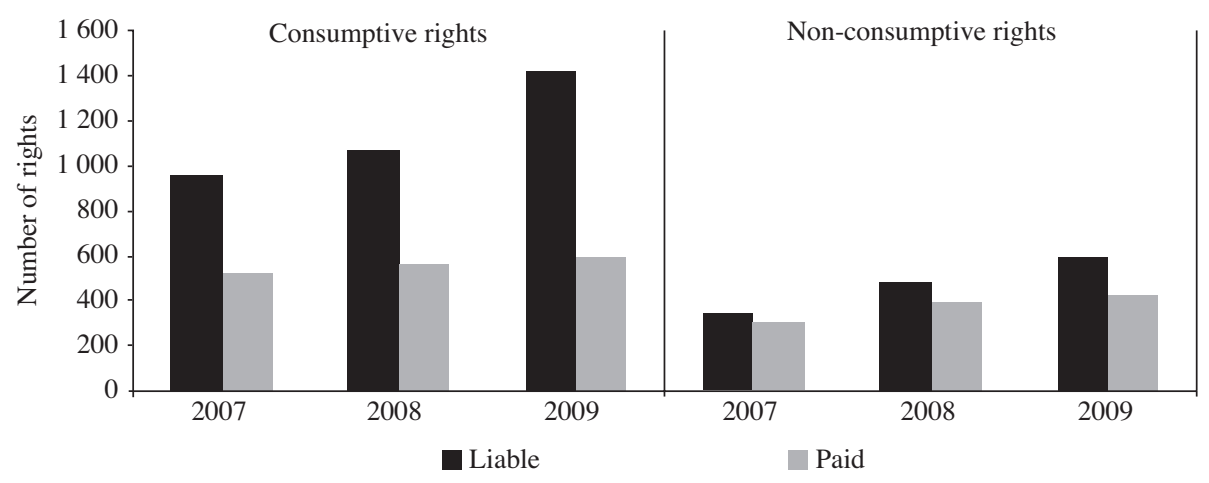

Source: prepared by the authors on the basis of Department of Water (DGA), Bases de datos del listado de derechos de aprovechamiento de aguas afectos a pago de patente por no uso, procesos 2007 a 2010, Santiago, Chile, Ministry of Public Works (MOP), 2010. 
TABLE 2

Largest non-use fees charged, consumptive rights, 2007-2010

\begin{tabular}{|c|c|c|c|c|c|c|c|}
\hline \multirow{2}{*}{ Owner } & \multirow{2}{*}{ Region } & \multirow{2}{*}{$\begin{array}{c}\text { Fee } \\
\text { (dollars) }\end{array}$} & \multirow{2}{*}{$\begin{array}{c}\text { Flow } \\
(l / s)\end{array}$} & \multicolumn{4}{|c|}{ Ranking } \\
\hline & & & & 2007 & 2008 & 2009 & 2010 \\
\hline María Estela García Constans & Valparaíso & 4498101 & 37787 & 1 & - & - & - \\
\hline Valle Rapel S.A. & Valparaíso & 3594988 & 30200 & - & 1 & - & - \\
\hline Valle Central S.A. & Valparaíso & 904699 & 7600 & - & 2 & - & - \\
\hline State. Department of Waterworks & Biobío & 644797 & 43333 & 2 & - & - & - \\
\hline State. Department of Waterworks & Biobío & 644797 & 43333 & 3 & - & - & - \\
\hline State. Department of Waterworks & Biobío & 644797 & 43333 & 4 & - & - & - \\
\hline Usuarios del Canal Biobío Sur & Biobío & 578313 & 38865 & 5 & - & - & - \\
\hline Agrícola y Comercial Los Lleuques Ltda. & Metropolitan & 553533 & 4650 & 6 & - & - & - \\
\hline Inversiones El Álamo S.A. & Metropolitan & 462765 & 3888 & - & 3 & 1 & - \\
\hline Alberto Acuña Puchi y Otros & Araucanía & 446398 & 30000 & 7 & 4 & 2 & 1 \\
\hline Proyectos de Aysén S.A. & Aysén & 446398 & 60000 & 8 & 5 & 3 & - \\
\hline Energía Austral Ltda. & & & & - & - & - & 2 \\
\hline Exploraciones, Inversiones y Asesorías Manantiales S.A. & Metropolitan & 404920 & 3402 & - & - & - & 3 \\
\hline Proyectos de Aysén S.A. & Aysén & 371998 & 5000 & 9 & 6 & 4 & - \\
\hline Energía Austral Ltda. & & & & - & - & - & 4 \\
\hline State. Department of Irrigation & Araucanía & 314586 & 21142 & 10 & - & - & - \\
\hline María Estela García Constans & Valparaíso & 312677 & 7880 & 11 & - & - & - \\
\hline Juan Landerretche Díaz y Otros & Biobío & 295366 & 19850 & - & 7 & - & - \\
\hline Comercial San Alberto Ltda. & Metropolitan & 273791 & 2300 & - & 8 & - & - \\
\hline Valle Rapel S.A. & Valparaíso & 249983 & 6300 & - & 9 & - & - \\
\hline Inversiones Quintay S.A. & Metropolitan & 231383 & 1944 & - & - & - & 5 \\
\hline Agrícola Las Acacias del Aconcagua S.A. & Metropolitan & 231383 & 1944 & - & - & - & 6 \\
\hline Inversiones Quintay S.A. & Metropolitan & 219479 & 1844 & - & 10 & 5 & - \\
\hline Inversiones Arlequín Ltda. & Coquimbo & 158719 & 4000 & - & - & - & 7 \\
\hline Inversiones Arlequín Ltda. & Valparaíso & 148799 & 1250 & 12 & 11 & 6 & 8 \\
\hline Gonzalo Donato Quezada Pressac & Metropolitan & 140109 & 1177 & - & - & 7 & - \\
\hline Hidroeléctrica Guardia Vieja S.A. & Valparaíso & 134068 & 1126 & 13 & - & - & - \\
\hline Agrícola Los Retoños S.A. & Valparaíso & 122015 & 1025 & 14 & 12 & - & - \\
\hline Jorge Schmidt y Cía. Ltda. & & & & - & - & 8 & - \\
\hline Humberto Einar y Otro & Valparaíso & 119039 & 1000 & - & - & 9 & - \\
\hline
\end{tabular}

Source: prepared by the authors on the basis of Department of Water (DGA), Bases de datos del listado de derechos de aprovechamiento de aguas afectos a pago de patente por no uso, procesos 2007 a 2010, Santiago, Chile, Ministry of Public Works (MOP), 2010.

Note: Records shaded in grey are water rights whose owners changed between non-use fee payment rounds. 


\section{Largest non-use fees charged, non-consumptive rights, 2007-2010}

\begin{tabular}{|c|c|c|c|c|c|c|c|}
\hline \multirow{2}{*}{ Owner } & \multirow{2}{*}{ Region } & \multirow{2}{*}{$\begin{array}{c}\text { Fee } \\
\text { (dollars) }\end{array}$} & \multirow{2}{*}{$\begin{array}{l}\text { Flow } \\
(l / s)\end{array}$} & \multicolumn{4}{|c|}{ Ranking } \\
\hline & & & & 2007 & 2008 & 2009 & 2010 \\
\hline ENDESA S.A. & Los Lagos & 3526876 & 850 & 1 & 1 & 1 & 1 \\
\hline Juan Wenke Williams & Valparaíso & 2393807 & 2 & - & 2 & - & - \\
\hline ENDESA S.A. & Biobío & 1189538 & 255 & - & - & - & 2 \\
\hline Beatriz Cortés Torres & Maule & 618707 & 60 & 2 & 3 & - & - \\
\hline Inversiones Arlequín Ltda. & & & & - & - & 2 & - \\
\hline Hidroeléctrica Centinela Ltda. & & & & - & - & - & 3 \\
\hline ENDESA S.A. & Los Ríos & 478276 & 48 & - & 4 & 3 & 4 \\
\hline ENDESA S.A. & Maule & 472623 & 25 & 3 & 5 & 4 & 5 \\
\hline ENDESA S.A. & Los Lagos & 438251 & 255 & 4 & 6 & 5 & 6 \\
\hline AES Gener S.A. & Metropolitan & 407365 & 61 & - & 7 & - & - \\
\hline AES Gener S.A. & Metropolitan & 405106 & 15 & - & 8 & 6 & 7 \\
\hline ENDESA S.A. & Maule & 392830 & 80 & 5 & - & - & - \\
\hline Colbún S.A. & & & & - & 9 & 7 & 8 \\
\hline AES Gener S.A. & Metropolitan & 353915 & 31 & - & 10 & 8 & 9 \\
\hline Hernán Lacalle Soza y Otros & Los Lagos & 318192 & 270 & 6 & - & - & - \\
\hline Colbún S.A. & & & & - & 11 & 9 & 10 \\
\hline Chilgener S.A. & Maule & 285784 & 19 & 7 & - & - & - \\
\hline AES Gener S.A. & & & & - & 12 & 10 & 11 \\
\hline Mediterráneo S.A. & Los Lagos & 257034 & 75 & - & - & - & 12 \\
\hline Jorge Wachholtz Buchholtz & O’Higgins & 243063 & 30 & - & - & - & 13 \\
\hline CGE Generación S.A. & Maule & 239994 & 23 & 8 & 13 & 11 & 14 \\
\hline ENDESA S.A. & Los Ríos & 223717 & 68 & - & 14 & 12 & 15 \\
\hline AES Gener S.A. & Metropolitan & 205622 & 25 & - & 15 & 13 & 16 \\
\hline CGE Generación S.A. & Biobío & 204272 & 52 & - & 16 & 14 & 17 \\
\hline AES Gener S.A. & Metropolitan & 200343 & 30 & - & - & 15 & 18 \\
\hline CGE Generación S.A. & Maule & 190031 & 18 & 9 & 17 & 16 & 19 \\
\hline AES Gener S.A. & Metropolitan & 183651 & 36 & - & 18 & - & 20 \\
\hline Compañía Forestal Chiloé & Los Lagos & 178861 & 47 & 10 & 19 & 17 & - \\
\hline Inversiones y Desarrollo Sur S.A. & & & & - & - & - & 21 \\
\hline Forestal Cholguán S.A. & Biobío & 172354 & 130 & - & - & 18 & 22 \\
\hline
\end{tabular}

Source: prepared by the authors on the basis of Department of Water (DGA), Bases de datos del listado de derechos de aprovechamiento de aguas afectos a pago de patente por no uso, procesos 2007 a 2010, Santiago, Chile, Ministry of Public Works (MOP), 2010.

Note: Records shaded in grey are water rights whose owners changed between non-use fee payment rounds. 
Although the total fees charged for consumptive water rights have been less than the total for non-consumptive rights (see figure 2), it is important to consider flows (see figure 4), as there are large differences between the two types of rights. These differences are not accurately reflected in the fees charged, since fees for consumptive rights are calculated by the flow in litres per second, whereas for non-consumptive rights they are calculated in cubic metres per second (see equations (1) and (2)), a ratio of 1,000 to 1 .

As expected, only rights liable to the fee were surrendered, and there was further confirmation that the non-use fee was being more successful for consumptive rights than for non-consumptive ones, with figures of US\$ 4,365,908 and $58.4 \mathrm{~m}^{3} / \mathrm{s}$ (see table 4) and US\$ 28,476 and $11.1 \mathrm{~m}^{3} / \mathrm{s}$ (see table 5 ), respectively.

FIGURE 4

Flows liable to non-use fees and flows paid out on, 2007-2009

(Cubic metres per second: $\mathrm{m}^{3} / \mathrm{s}$ )

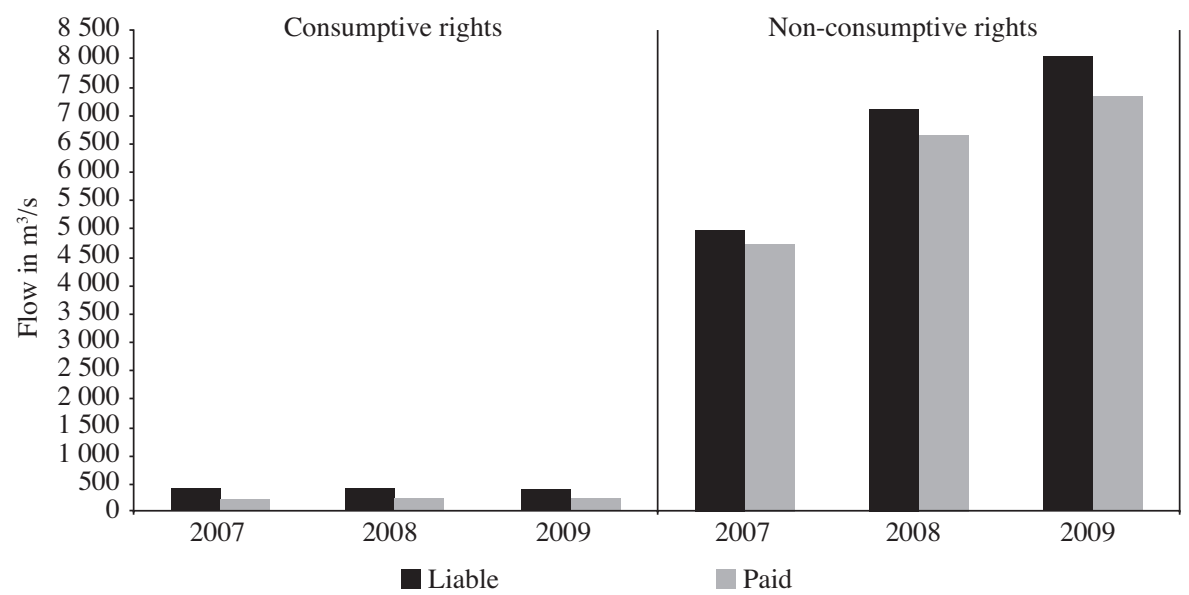

Source: prepared by the authors on the basis of Department of Water (DGA), Bases de datos del listado de derechos de aprovechamiento de aguas afectos a pago de patente por no uso, procesos 2007 a 2010, Santiago, Chile, Ministry of Public Works (MOP), 2010.

TABLE 4

Consumptive water rights surrendered, 2007-2010

\begin{tabular}{|c|c|c|c|c|}
\hline Owner & Region & Source & Flow $(l / s)$ & $\begin{array}{c}\text { Equivalent fee } \\
\text { (dollars) }\end{array}$ \\
\hline Valle Rapel S.A. & Valparaíso & Rapel river & 28527 & 3395836 \\
\hline Humberto Benedetti Rosenqvist & Valparaíso & Unnamed & 4570 & 544010 \\
\hline Valle Rapel S.A. & Valparaíso & Rapel river & 5579 & 221376 \\
\hline Bosques Cautín & Araucanía & Toltén river & 3500 & 52080 \\
\hline Corpora Agrícola S.A. & Valparaíso & Aconcagua river & 213 & 25296 \\
\hline Dora Elena Oelckers & Los Lagos & Pilmaiquén river & 10000 & 24797 \\
\hline Agrícola Paiquén & Valparaíso & Aconcagua river & 208 & 24760 \\
\hline Bosques Cautín & Araucanía & Imperial river & 1500 & 22320 \\
\hline Ganadera Río Caleta Ltda. & Magallanes & La Caleta river & 1951 & 14515 \\
\hline Corpora Agrícola S.A. & Valparaíso & Aconcagua river & 255 & 10118 \\
\hline Agrícola Paiquén & Valparaíso & Aconcagua river & 250 & 9920 \\
\hline Bosques Cautín & Araucanía & Cholchol river & 667 & 9917 \\
\hline Margarita Yutronich & Magallanes & Blanco river & 841 & 6257 \\
\hline José Irarrázaval Larraín & Araucanía & La Gaviota river & 219 & 3255 \\
\hline Rolando Hott Marquard & Araucanía & Huilío river & 88 & 1302 \\
\hline Total & & & 58386 & 4365908 \\
\hline
\end{tabular}

Source: Department of Water (DGA), Informe sobre patente por no uso de derechos de aprovechamiento de aguas, Santiago, Chile, Ministry of Public Works (MOP), 2010. 


\begin{tabular}{|c|c|c|c|c|}
\hline Owner & Region & Source & Flow $(l / s)$ & $\begin{array}{l}\text { Equivalent fee } \\
\text { (dollars) }\end{array}$ \\
\hline Soc. Agrícola y Forestal Degenfield & Los Lagos & Cahulnalhue river & 4259 & 26144 \\
\hline Rolando Polh Marquard & Araucanía & Palguín river & 2000 & 982 \\
\hline Soc. Agrícola y Forestal Degenfield & Los Lagos & Cahulnalhue river & 1752 & 513 \\
\hline Bosques Cautín & Araucanía & Imperial river & 1500 & 368 \\
\hline Bosques Cautín & Araucanía & Cholchol river & 1083 & 346 \\
\hline Bosques Cautín & Araucanía & Toltén river & 500 & 123 \\
\hline Total & & & 11094 & 28476 \\
\hline
\end{tabular}

Source: Department of Water (DGA), Informe sobre patente por no uso de derechos de aprovechamiento de aguas, Santiago, Chile, Ministry of Public Works (MOP), 2010.

Up and down the country, there are substantial differences in the total macrozonal fees charged for consumptive rights (see tables 6, 7 and 8). In the different rounds, the largest portion of the total charged has been in the north-centre macrozone (arid and semiarid zone), as in this part of Chile the equation for calculating the non-use fee is weighted by a constant of 1.6, whereas in the centre-south and south-far south macrozones it is weighted by constants of 0.2 and 0.1 , respectively (see equation (1)), the result being that total fees charged are less in these latter two macrozones.

Where fee revenue is concerned, the differing availability of water by latitude within Chile (with scarcity diminishing from north to south) and the macrozonal constants for calculating fees on consumptive water rights have resulted in payment percentages varying between regions in the same macrozone. One effect of this difference can be exemplified by the case of two neighbouring regions

TABLE 6

Total regional non-use fees charged and paid, consumptive rights, 2007

\begin{tabular}{|c|c|c|c|c|c|c|c|c|c|}
\hline \multirow{2}{*}{ Region } & \multicolumn{3}{|c|}{$\begin{array}{c}\text { Fees } \\
\text { (dollars) }\end{array}$} & \multicolumn{3}{|c|}{$\begin{array}{l}\text { Number of rights } \\
\text { (units) }\end{array}$} & \multicolumn{3}{|c|}{$\begin{array}{l}\text { Flow } \\
\left(\mathrm{m}^{3} / \mathrm{s}\right)\end{array}$} \\
\hline & Charged & Paid & Percentage & Liable & Paid & Percentage & Liable & Paid & Percentage \\
\hline Arica y Parinacota & 3333 & 3333 & 100.0 & 1 & 1 & 100.0 & 0028 & 0028 & 100.0 \\
\hline Tarapacá & 117992 & 116682 & 98.9 & 23 & 21 & 91.3 & 0991 & 0980 & 98.9 \\
\hline Antofagasta & 437185 & 428674 & 98.1 & 59 & 55 & 93.2 & 3673 & 3601 & 98.1 \\
\hline Atacama & 594777 & 406575 & 68.4 & 97 & 63 & 64.9 & 4996 & 3415 & 68.4 \\
\hline Coquimbo & 475872 & 396580 & 83.3 & 47 & 38 & 80.9 & 3998 & 3332 & 83.3 \\
\hline Valparaíso & 6367626 & 777629 & 12.2 & 116 & 53 & 45.7 & 62240 & 7917 & 12.7 \\
\hline Metropolitan & 1312339 & 309098 & 23.6 & 115 & 47 & 40.9 & 11687 & 2577 & 22.0 \\
\hline North-centre macrozone & 9309123 & 2438571 & 26.2 & 458 & 278 & 60.7 & 87612 & 21850 & 24.9 \\
\hline O'Higgins & 38744 & 14515 & 37.5 & 31 & 14 & 45.2 & 2681 & 0976 & 36.4 \\
\hline Maule & 125102 & 34489 & 27.6 & 65 & 19 & 29.2 & 11171 & 3159 & 28.3 \\
\hline Biobío & 86364 & 13612 & 15.8 & 14 & 5 & 35.7 & 5923 & 0915 & 15.4 \\
\hline Araucanía & 879953 & 236726 & 26.9 & 135 & 64 & 47.4 & 65644 & 20327 & 31.0 \\
\hline Centre-south macrozone & 1130163 & 299343 & 26.5 & 245 & 102 & 41.6 & 85418 & 25376 & 29.7 \\
\hline Los Ríos & 150911 & 101582 & 67.3 & 104 & 72 & 69.2 & 23335 & 14810 & 63.5 \\
\hline Los Lagos & 159532 & 82670 & 51.8 & 45 & 31 & 68.9 & 28585 & 11588 & 40.5 \\
\hline Aysén & 932360 & 895497 & 96.0 & 21 & 8 & 38.1 & 145498 & 140208 & 96.4 \\
\hline Magallanes & 299019 & 53402 & 17.9 & 85 & 30 & 35.3 & 50607 & 10592 & 20.9 \\
\hline South-far south macrozone & 1541822 & 1133152 & 73.5 & 255 & 141 & 55.3 & 248025 & 177197 & 71.4 \\
\hline Total & 11981107 & 3871065 & 32.3 & 958 & 521 & 54.4 & 421055 & 224423 & 53.3 \\
\hline
\end{tabular}

Source: prepared by the authors on the basis of Department of Water (DGA), Bases de datos del listado de derechos de aprovechamiento de aguas afectos a pago de patente por no uso, procesos 2007 a 2010, Santiago, Chile, Ministry of Public Works (MOP), 2010. 
with similar hydrological conditions: the Metropolitan and O'Higgins regions. In the 2009 round (see table 8), the flow liable to payment of a non-use fee was found to be similar (15.39 and $11.42 \mathrm{~m} / \mathrm{s}$, respectively), but the sum total of fees charged was very different (US\$1,688,064 and US $\$ 153,158$, respectively) as, predictably, were the ratios between the amounts paid and the amounts charged (31.2\% and $87.2 \%$, respectively).

TABLE 7

Total regional non-use fees charged and paid, consumptive rights, 2008

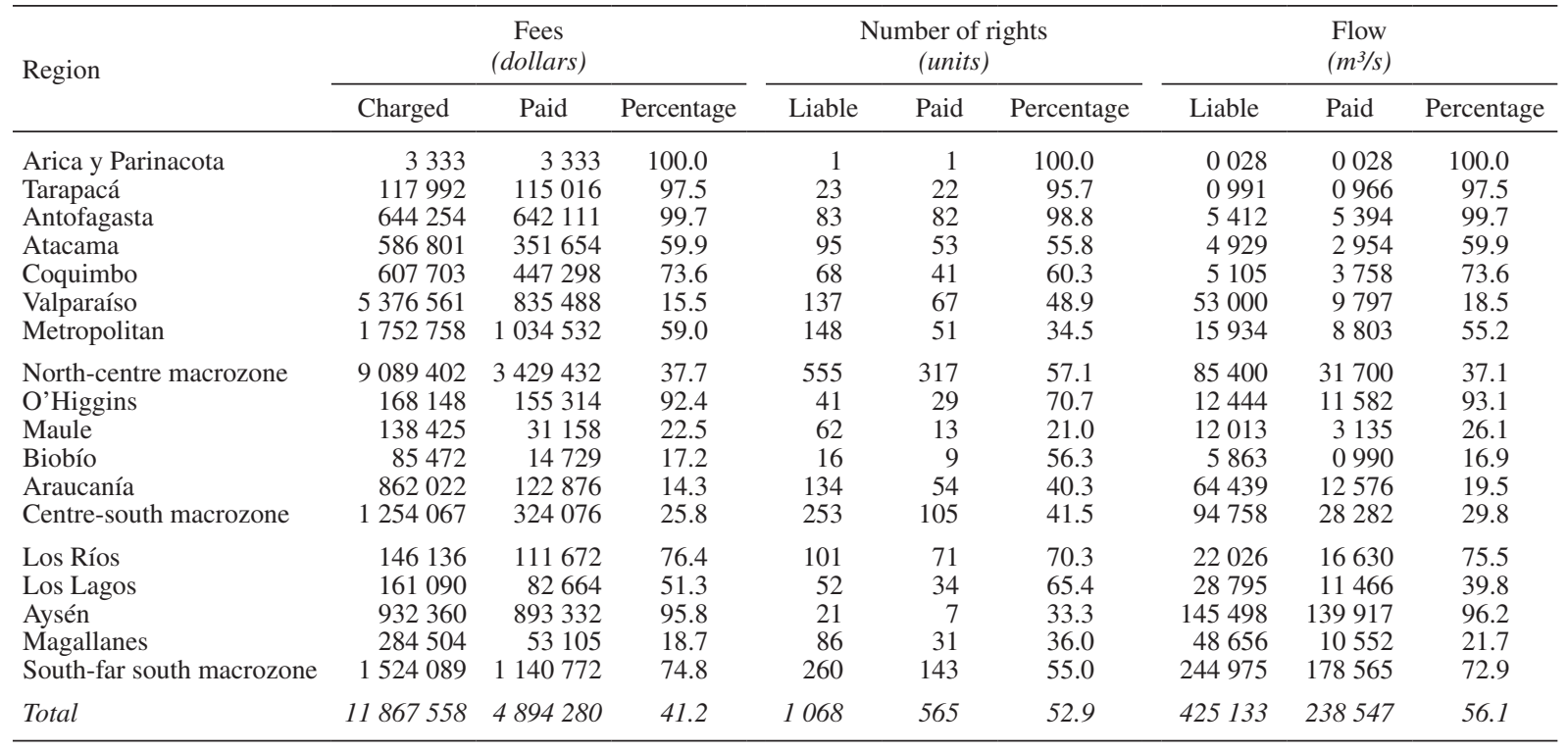

Source: prepared by the authors on the basis of Department of Water (DGA), Bases de datos del listado de derechos de aprovechamiento de aguas afectos a pago de patente por no uso, procesos 2007 a 2010, Santiago, Chile, Ministry of Public Works (MOP), 2010.

TABLE 8

Total regional non-use fees charged and paid, consumptive rights, 2009

\begin{tabular}{|c|c|c|c|c|c|c|c|c|c|}
\hline \multirow{2}{*}{ Region } & \multicolumn{3}{|c|}{$\begin{array}{c}\text { Fees } \\
(\text { dollars })\end{array}$} & \multicolumn{3}{|c|}{$\begin{array}{c}\text { Number of rights } \\
\text { (units) }\end{array}$} & \multicolumn{3}{|c|}{$\begin{array}{l}\text { Flow } \\
\left(m^{3} / s\right)\end{array}$} \\
\hline & Charged & Paid & Percentage & Liable & Paid & Percentage & Liable & Paid & Percentage \\
\hline Arica y Parinacota & 35871 & 13253 & 36.9 & 6 & 4 & 66.7 & 0508 & 0198 & 39.0 \\
\hline Tarapacá & 129646 & 115123 & 88.8 & 27 & 24 & 88.9 & 1089 & 0967 & 88.8 \\
\hline Antofagasta & 726190 & 724047 & 99.7 & 84 & 83 & 98.8 & 6125 & 6107 & 99.7 \\
\hline Atacama & 606220 & 346881 & 57.2 & 109 & 51 & 46.8 & 5359 & 2914 & 54.4 \\
\hline Valparaíso & 1421693 & 644577 & 45.3 & 181 & 72 & 39.8 & 14852 & 6784 & 45.7 \\
\hline Metropolitan & 1688064 & 525992 & 31.2 & 163 & 46 & 28.2 & 15390 & 4461 & 29.0 \\
\hline North-centre macrozone & 5124138 & 2610930 & 51.0 & 628 & 313 & 49.8 & 47663 & 23457 & 49.2 \\
\hline O’Higgins & 153158 & 133483 & 87.2 & 44 & 26 & 59.1 & 11421 & 10021 & 87.7 \\
\hline Maule & 191522 & 81816 & 42.7 & 60 & 13 & 21.7 & 23815 & 14896 & 62.5 \\
\hline Biobío & 152559 & 29969 & 19.6 & 27 & 14 & 51.9 & 10371 & 2133 & 20.6 \\
\hline Araucanía & 851927 & 102654 & 12.0 & 187 & 41 & 21.9 & 63266 & 9499 & 15.0 \\
\hline Centre-south macrozone & 1349166 & 347922 & 25.8 & 318 & 94 & 29.6 & 108873 & 36548 & 33.6 \\
\hline Los Ríos & 254224 & 173932 & 68.4 & 214 & 121 & 56.5 & 38196 & 26275 & 68.8 \\
\hline Los Lagos & 204346 & 48331 & 23.7 & 151 & 46 & 30.5 & 28965 & 6629 & 22.9 \\
\hline Aysén & 933759 & 891431 & 95.5 & 25 & 5 & 20.0 & 146024 & 139150 & 95.3 \\
\hline Magallanes & 276200 & 18379 & 6.7 & 79 & 16 & 20.3 & 47175 & 3114 & 6.6 \\
\hline South-far south macrozone & 1668529 & 1132073 & 67.8 & 469 & 188 & 40.1 & 260360 & 175169 & 67.3 \\
\hline Total & 8141833 & 4090926 & 50.2 & 1415 & 595 & 42.0 & 416895 & 235174 & 56.4 \\
\hline
\end{tabular}

Source: prepared by the authors on the basis of Department of Water (DGA), Bases de datos del listado de derechos de aprovechamiento de aguas afectos a pago de patente por no uso, procesos 2007 a 2010, Santiago, Chile, Ministry of Public Works (MOP), 2010. 
Where non-consumptive water rights are concerned, the percentage of fees charged that is actually paid is high in all regions, and the fee calculation constants (see equation (2)) are not a determining factor. With nonconsumptive rights, furthermore, unlike consumptive ones, the largest fee amounts are charged in the centresouth and south-far south macrozones (see tables 9, 10 and 11), for two reasons:

(i) whereas consumptive and non-consumptive rights that were originally less than 10 and $100 \mathrm{l} / \mathrm{s}$, respectively, are exempt from fee payment in the north-centre macrozone, in the other macrozones these values are 50 and $500 \mathrm{l} / \mathrm{s}$, so that a larger number of rights are excluded from the payment list from the O'Higgins Region southward; and

(ii) non-consumptive rights, predominantly used for hydroelectricity, are concentrated in southern Chile, where the conditions for generating this type of power are better than in the north.

Lastly, one thing that might explain the almost $100 \%$ take from fees on non-consumptive rights (see tables 9, 10 and 11) is the considerable economic power of the owners of rights of this type (mainly hydroelectric companies and their investors), whereas the owners of consumptive rights operate in different sectors and have differing levels of financial capacity (see tables 12 and 13).

\begin{tabular}{|c|c|c|c|c|c|c|c|c|c|}
\hline \multirow{2}{*}{ Region } & \multicolumn{3}{|c|}{$\begin{array}{c}\text { Fees } \\
\text { (dollars) }\end{array}$} & \multicolumn{3}{|c|}{$\begin{array}{l}\text { Number of rights } \\
\text { (units) }\end{array}$} & \multicolumn{3}{|c|}{$\begin{array}{l}\text { Flow } \\
\left(\mathrm{m}^{3} / \mathrm{s}\right)\end{array}$} \\
\hline & Charged & Paid & Percentage & Liable & Paid & Percentage & Liable & Paid & Percentage \\
\hline Arica y Parinacota & - & - & - & - & - & - & - & - & - \\
\hline Tarapacá & - & - & - & - & - & - & - & - & - \\
\hline Antofagasta & - & - & - & - & - & - & - & - & - \\
\hline Atacama & - & - & - & - & - & - & - & - & - \\
\hline Coquimbo & 6064 & 6064 & 100.0 & 1 & 1 & 100.0 & 19000 & 19000 & 100.0 \\
\hline Valparaíso & 185813 & 185813 & 100.0 & 6 & 6 & 100.0 & 19525 & 19525 & 100.0 \\
\hline Metropolitan & 1324214 & 1317923 & 99.5 & 41 & 38 & 92.7 & 329632 & 326223 & 99.0 \\
\hline North-centre macrozone & 1516091 & 1509800 & 99.6 & 48 & 45 & 93.8 & 368157 & 364748 & 99.1 \\
\hline O’Higgins & 637869 & 522966 & 82.0 & 22 & 20 & 90.9 & 178766 & 126766 & 70.9 \\
\hline Maule & 3328385 & 3295027 & 99.0 & 29 & 24 & 82.8 & 695142 & 675225 & 97.1 \\
\hline Biobío & 223422 & 223422 & 100.0 & 14 & 14 & 100.0 & 262997 & 262997 & 100.0 \\
\hline Araucanía & 687409 & 618827 & 90.0 & 56 & 48 & 85.7 & 481729 & 362929 & 75.3 \\
\hline Centre-south macrozone & 4877084 & 4660241 & 95.6 & 121 & 106 & 87.6 & 1618634 & 1427918 & 88.2 \\
\hline Los Ríos & 2643369 & 2637565 & 99.8 & 85 & 83 & 97.6 & 1197965 & 1195969 & 99.8 \\
\hline Los Lagos & 4209094 & 4173071 & 99.1 & 67 & 55 & 82.1 & 1548904 & 1518253 & 98.0 \\
\hline Aysén & 116026 & 114771 & 98.9 & 8 & 6 & 75.0 & 219623 & 209064 & 95.2 \\
\hline Magallanes & 6861 & 5313 & 77.4 & 15 & 10 & 66.7 & 20754 & 16251 & 78.3 \\
\hline South-far south macrozone & 6975349 & 6930720 & 99.4 & 175 & 154 & 88.0 & 2987246 & 2939537 & 98.4 \\
\hline Total & 13368525 & 13100762 & 98.0 & 344 & 305 & 88.7 & 4974037 & 4732202 & 95.1 \\
\hline
\end{tabular}

Source: prepared by the authors on the basis of Department of Water (DGA), Bases de datos del listado de derechos de aprovechamiento de aguas afectos a pago de patente por no uso, procesos 2007 a 2010, Santiago, Chile, Ministry of Public Works (MOP), 2010. 
Total regional non-use fees charged and paid, non-consumptive rights, 2008

\begin{tabular}{|c|c|c|c|c|c|c|c|c|c|}
\hline \multirow{2}{*}{ Region } & \multicolumn{3}{|c|}{$\begin{array}{c}\text { Fees } \\
\text { (dollars) }\end{array}$} & \multicolumn{3}{|c|}{$\begin{array}{l}\text { Number of rights } \\
\text { (units) }\end{array}$} & \multicolumn{3}{|c|}{$\begin{array}{l}\text { Flow } \\
\left(\mathrm{m}^{3} / \mathrm{s}\right)\end{array}$} \\
\hline & Charged & Paid & Percentage & Liable & Paid & Percentage & Liable & Paid & Percentage \\
\hline Arica y Parinacota & - & - & - & - & - & - & - & - & - \\
\hline Tarapacá & - & - & - & - & - & - & - & - & - \\
\hline Antofagasta & - & - & - & - & - & - & - & - & - \\
\hline Atacama & - & - & - & - & - & - & - & - & - \\
\hline Coquimbo & 6064 & 6064 & 100.0 & 1 & 1 & 100.0 & 19000 & 19000 & 100.0 \\
\hline Valparaíso & 186917 & 93252 & 49.9 & 7 & 6 & 85.7 & 19710 & 12710 & 64.5 \\
\hline Metropolitan & 2276787 & 2267453 & 99.6 & 50 & 45 & 90.0 & 458745 & 454507 & 99.1 \\
\hline North-centre macrozone & 2469768 & 2366769 & 95.8 & 58 & 52 & 89.7 & 497455 & 486216 & 97.7 \\
\hline O'Higgins & 1170448 & 1169585 & 99.9 & 38 & 37 & 97.4 & 281608 & 280906 & 99.8 \\
\hline Maule & 3347907 & 3327924 & 99.4 & 32 & 26 & 81.3 & 699550 & 678134 & 96.9 \\
\hline Biobío & 1455336 & 1041819 & 71.6 & 32 & 27 & 84.4 & 634520 & 500707 & 78.9 \\
\hline Araucanía & 1145818 & 1049429 & 91.6 & 82 & 60 & 73.2 & 1157908 & 998526 & 86.2 \\
\hline Los Ríos & 2951593 & 2915768 & 98.8 & 125 & 103 & 82.4 & 1995057 & 1948879 & 97.7 \\
\hline Los Lagos & 4235675 & 4212171 & 99.4 & 104 & 77 & 74.0 & 1608296 & 1550983 & 96.4 \\
\hline Aysén & 122739 & 118909 & 96.9 & 9 & 6 & 66.7 & 223793 & 208515 & 93.2 \\
\hline Magallanes & 701 & 701 & 100.0 & 6 & 6 & 100.0 & 6171 & 6171 & 100.0 \\
\hline South-far south macrozone & 7310708 & 7247548 & 99.1 & 244 & 192 & 78.7 & 3833317 & 3714549 & 96.9 \\
\hline Total & 16899986 & 16203075 & 95.9 & 486 & 394 & 81.1 & 7104360 & 6659038 & 93.7 \\
\hline
\end{tabular}

Source: prepared by the authors on the basis of Department of Water (DGA), Bases de datos del listado de derechos de aprovechamiento de aguas afectos a pago de patente por no uso, procesos 2007 a 2010, Santiago, Chile, Ministry of Public Works (MOP), 2010.

TABLE 11

Total regional non-use fees charged and paid, non-consumptive rights, 2009

\begin{tabular}{|c|c|c|c|c|c|c|c|c|c|}
\hline \multirow{2}{*}{ Region } & \multicolumn{3}{|c|}{$\begin{array}{c}\text { Fees } \\
(\text { dollars })\end{array}$} & \multicolumn{3}{|c|}{$\begin{array}{l}\text { Number of rights } \\
\text { (units) }\end{array}$} & \multicolumn{3}{|c|}{$\begin{array}{l}\text { Flow } \\
\left(\mathrm{m}^{3} / \mathrm{s}\right)\end{array}$} \\
\hline & Charged & Paid & Percentage & Charged & Paid & Percentage & Charged & Paid & Percentage \\
\hline Arica y Parinacota & - & - & - & - & - & - & - & - & - \\
\hline Tarapacá & 1107 & - & - & 1 & - & - & 0150 & - & - \\
\hline Antofagasta & - & - & - & - & - & - & - & - & - \\
\hline Atacama & - & - & - & - & - & - & - & - & - \\
\hline Coquimbo & 6064 & 6064 & 100.0 & 1 & 1 & 100.0 & 19000 & 19000 & 100.0 \\
\hline Valparaíso & 100022 & 99967 & 99.9 & 5 & 4 & 80.0 & 7932 & 7710 & 97.2 \\
\hline Metropolitan & 2327341 & 2319171 & 99.6 & 55 & 51 & 92.7 & 467745 & 464447 & 99.3 \\
\hline North-centre macrozone & 2434534 & 2425203 & 99.6 & 62 & 56 & 90.3 & 494828 & 491156 & 99.3 \\
\hline O’Higgins & 1083655 & 1073045 & 99.0 & 37 & 35 & 94.6 & 279956 & 277268 & 99.0 \\
\hline Maule & 3369928 & 3369069 & 100.0 & 31 & 29 & 93.5 & 700510 & 697010 & 99.5 \\
\hline Biobío & 1740568 & 1519655 & 87.3 & 49 & 41 & 83.7 & 1273248 & 1132618 & 89.0 \\
\hline Araucanía & 1610266 & 1181803 & 73.4 & 129 & 72 & 55.8 & 1433868 & 1061545 & 74.0 \\
\hline Los Ríos & 3026896 & 3005939 & 99.3 & 132 & 111 & 84.1 & 2007726 & 1947329 & 97.0 \\
\hline Los Lagos & 4293016 & 4229998 & 98.5 & 139 & 73 & 52.5 & 1609799 & 1508401 & 93.7 \\
\hline Aysén & 122834 & 121484 & 98.9 & 10 & 8 & 80.0 & 223793 & 213235 & 95.3 \\
\hline Magallanes & 389 & 306 & 78.8 & 2 & 1 & 50.0 & 3383 & 1870 & 55.3 \\
\hline South-far south macrozone & 7443134 & 7357727 & 98.9 & 283 & 193 & 68.2 & 3844702 & 3670836 & 95.5 \\
\hline Total & 17682085 & 16926502 & 95.7 & 591 & 426 & 72.1 & 8027112 & 7330434 & 91.3 \\
\hline
\end{tabular}

Source: prepared by the authors on the basis of Department of Water (DGA), Bases de datos del listado de derechos de aprovechamiento de aguas afectos a pago de patente por no uso, procesos 2007 a 2010, Santiago, Chile, Ministry of Public Works (MOP), 2010. 
TABLE 12

Owners of water rights liable to the highest non-use fees, 2010

\begin{tabular}{|c|c|c|c|c|c|}
\hline Ranking & Owner & Sector & $\begin{array}{c}\text { Fees } \\
\text { (dollars) }\end{array}$ & $\begin{array}{l}\text { Number of rights } \\
\text { (units) }\end{array}$ & $\begin{array}{l}\text { Flow } \\
\left(\mathrm{m}^{3} / \mathrm{s}\right)\end{array}$ \\
\hline 1 & ENDESA S.A. & Hydroelectricity & 6478281 & 17 & 157505 \\
\hline 2 & AES Gener S.A. & Hydroelectricity & 3549024 & 58 & 115632 \\
\hline 3 & Colbún S.A. & Hydroelectricity & 1771140 & 22 & 151402 \\
\hline 4 & CGE Generación S.A. & Hydroelectricity & 1183343 & 16 & 49553 \\
\hline 5 & Hidroeléctrica Trayenko S.A. & Hydroelectricity & 1085390 & 46 & 25952 \\
\hline 6 & Inversiones Arlequín Ltda. & Investment & 549584 & 11 & 1351 \\
\hline 7 & CODELCO & Mining & 378603 & 22 & 755 \\
\hline 8 & Hidroeléctrica La Higuera S.A. & Hydroelectricity & 286177 & 13 & 6560 \\
\hline 9 & Exploraciones, Inversiones y Asesorías Huturi S.A. & Investment & 274127 & 29 & 12019 \\
\hline 10 & Hidroeléctrica La Confluencia S.A. & Hydroelectricity & 233485 & 8 & 5920 \\
\hline 11 & Exploraciones, Inversiones y Asesorías Mundo S.A. & Investment & 121658 & 15 & 102 \\
\hline 12 & Forestal Valdivia S.A. & Forestry & 118157 & 10 & 1475 \\
\hline 13 & Álvaro Flaño García & Natural person & 77252 & 10 & 6612 \\
\hline 14 & Maderera Panguipulli S.A. & Forestry & 49119 & 12 & 5041 \\
\hline 15 & Eléctrica Panguipulli S.A. & Hydroelectricity & 38565 & 11 & 9485 \\
\hline \multirow{2}{*}{\multicolumn{3}{|c|}{$\begin{array}{l}\text { Total } \\
\text { Share of total }\end{array}$}} & 16193906 & 300 & 549366 \\
\hline & & & $52.0 \%$ & $10.0 \%$ & $51.6 \%$ \\
\hline
\end{tabular}

Source: prepared by the authors on the basis of Department of Water (DGA), Bases de datos del listado de derechos de aprovechamiento de aguas afectos a pago de patente por no uso, procesos 2007 a 2010, Santiago, Chile, Ministry of Public Works (MOP), 2010.

TABLE 13

Total non-use fees charged by sector, 2010

\begin{tabular}{|c|c|c|c|c|c|c|}
\hline Sector & $\begin{array}{c}\text { Fees } \\
\text { (dollars) }\end{array}$ & Percentage & $\begin{array}{l}\text { Number of rights } \\
\text { (units) }\end{array}$ & Percentage & $\begin{array}{l}\text { Flow } \\
\left(\mathrm{m}^{3} / \mathrm{s}\right)\end{array}$ & Percentage \\
\hline Natural persons & 4068945 & 13.1 & 1329 & 44.3 & 1345.3 & 12.6 \\
\hline Agriculture & 1583207 & 5.1 & 376 & 12.5 & 904.6 & 8.5 \\
\hline Fishing and aquaculture & 78534 & 0.3 & 90 & 3.0 & 157.3 & 1.5 \\
\hline Mining & 897647 & 2.9 & 163 & 5.4 & 15.3 & 0.1 \\
\hline Forestry & 561805 & 1.8 & 78 & 2.6 & 239.3 & 2.2 \\
\hline Hydroelectricity & 18187182 & 58.4 & 279 & 9.3 & 7544.7 & 70.9 \\
\hline Sanitary services & 712931 & 2.3 & 98 & 3.3 & 14.8 & 0.1 \\
\hline Real estate & 319953 & 1.0 & 83 & 2.8 & 19.5 & 0.2 \\
\hline Non-profit organizations & 60870 & 0.2 & 40 & 1.3 & 6.5 & 0.1 \\
\hline Other legal entities & 4650271 & 14.9 & 466 & 15.5 & 396.2 & 3.7 \\
\hline Total & 31121345 & 100.0 & 3002 & 100.0 & 10643.5 & 100.0 \\
\hline
\end{tabular}

Source: prepared by the authors on the basis of Department of Water (DGA), Bases de datos del listado de derechos de aprovechamiento de aguas afectos a pago de patente por no uso, procesos 2007 a 2010, Santiago, Chile, Ministry of Public Works (MOP), 2010. 


\section{The market price of rights relative to non-use fees}

Estimates of average market prices for consumptive rights yield very varied results in the different regions. When these figures are compared with a non-use fee differentiated into three macrozones of application, disparities are found in the number of years of fee payment that would be required to exceed the average market price of rights. Whereas in the Arica y Parinacota, Coquimbo, Valparaíso, Metropolitan, Los Lagos and Magallanes regions the number of years of cumulative fee payment needed to exceed the average market price ranges from 18 to 22, in Antofagasta and Atacama the period is about 100 years (see table 14). This situation is ultimately reflected in differences in willingness to pay, since the non-use fee will be a smaller burden for owners who are being charged a fee representing only a tiny fraction of the price their rights could command in the marketplace than for those who are having to pay a fee representing a substantial percentage of the price of their rights, something that can be observed by contrasting the payment percentages in tables 6, 7 and 8 with the data in table 14 .

For non-consumptive rights, data were obtained on just eight transactions that could be used to calculate the equivalent fee. Although there are considerable price differences, it is difficult to make a comparison on this basis, as the rights traded differ in a number of respects such as flow, exercise and height difference between the extraction and return points. Nonetheless, the number of years of fee payment needed to exceed the transaction price allows the differences to be contrasted (see table 15). Having isolated market prices rather than average ones as with consumptive rights makes it difficult to use criterion $\mathrm{C}$ to assess whether the fee for non-consumptive rights is sufficient to discourage non-use. However, it would take over two centuries of fee payment to match the prices that some rights of this kind would go for in the market, which appears to support the idea that the design of the non-use fee has been lax where nonconsumptive rights are concerned.

TABLE 14

Estimated market price and cumulative regional non-use fees for permanent, continuous consumptive rights of $50 \mathrm{l} / \mathrm{s}$

\begin{tabular}{|c|c|c|c|c|c|c|c|c|c|c|}
\hline \multirow{2}{*}{ Region } & \multirow{2}{*}{$\begin{array}{l}\text { Estimated } \\
\text { average } \\
\text { market price } \\
\text { (dollars) }\end{array}$} & \multicolumn{8}{|c|}{$\begin{array}{c}\text { Cumulative fees } \\
\text { (dollars) }\end{array}$} & \multirow{2}{*}{$\begin{array}{c}\text { Years of fee } \\
\text { payment } \\
\text { needed to } \\
\text { exceed price }\end{array}$} \\
\hline & & Year 1 & Percentage & Year 5 & Percentage & Year 10 & Percentage & Year 15 & Percentage & \\
\hline Arica y Parinacota & 262177 & 5952 & 2.3 & 29760 & 11.4 & 89280 & 34.1 & 208319 & 79.5 & 18 \\
\hline Tarapacá & 1472769 & 5952 & 0.4 & 29760 & 2.0 & 89280 & 6.1 & 208319 & 14.1 & 69 \\
\hline Atacama & 2481823 & 5952 & 0.2 & 29760 & 1.2 & 89280 & 3.6 & 208319 & 8.4 & 111 \\
\hline Coquimbo & 337036 & 5952 & 1.8 & 29760 & 8.8 & 89280 & 26.5 & 208319 & 61.8 & 21 \\
\hline Valparaíso & 307981 & 5952 & 1.9 & 29760 & 9.7 & 89280 & 29.0 & 208319 & 67.6 & 20 \\
\hline Metropolitan & 274622 & 5952 & 2.2 & 29760 & 10.8 & 89280 & 32.5 & 208319 & 75.9 & 18 \\
\hline O’Higgins & 145904 & 744 & 0.5 & 3720 & 2.5 & 11160 & 7.6 & 26040 & 17.8 & 56 \\
\hline Maule & 115638 & 744 & 0.6 & 3720 & 3.2 & 11160 & 9.7 & 26040 & 22.5 & 46 \\
\hline Biobío & 85880 & 744 & 0.9 & 3720 & 4.3 & 11160 & 13.0 & 26040 & 30.3 & 36 \\
\hline Los Ríos & 43091 & 372 & 0.9 & 1860 & 4.3 & 5580 & 12.9 & 13020 & 30.2 & 36 \\
\hline Los Lagos & 22485 & 372 & 1.7 & 1860 & 8.3 & 5580 & 24.8 & 13020 & 57.9 & 22 \\
\hline Aysén & 54264 & 372 & 0.7 & 1860 & 3.4 & 5580 & 10.3 & 13020 & 24.0 & 43 \\
\hline Magallanes & 19182 & 372 & 1.9 & 1860 & 9.7 & 5580 & 29.1 & 13020 & 67.9 & 20 \\
\hline
\end{tabular}

Source: prepared by the authors on the basis of Department of Water (DGA), Base de datos de transacciones de derechos de aprovechamiento a diciembre de 2009 informadas por los Conservadores de Bienes Raíces, Santiago, Chile, Ministry of Public Works (MOP), 2009 [online] http:// www.dga.cl/administracionrecursoshidricos/cbr/Documents/2registrosmodificadoscbr.xls and Listado de remates de derechos de aprovechamiento de aguas realizados para situaciones en que dos o más solicitudes se contraponen, Santiago, Chile, Ministry of Public Works (MoP), 2010; José Pedro Gallo, Listado de remates de derechos de aprovechamiento de aguas realizados, Santiago, Chile, Remates Fernando Zañartu Rozas y Cía. Ltda., 2010; and Ministry of Public Works (MOP), Ley N²0.017: Modifica el Código de Aguas, Santiago, Chile, 2005 [online] http:// www.leychile.cl/Navegar?idNorma=239221. 


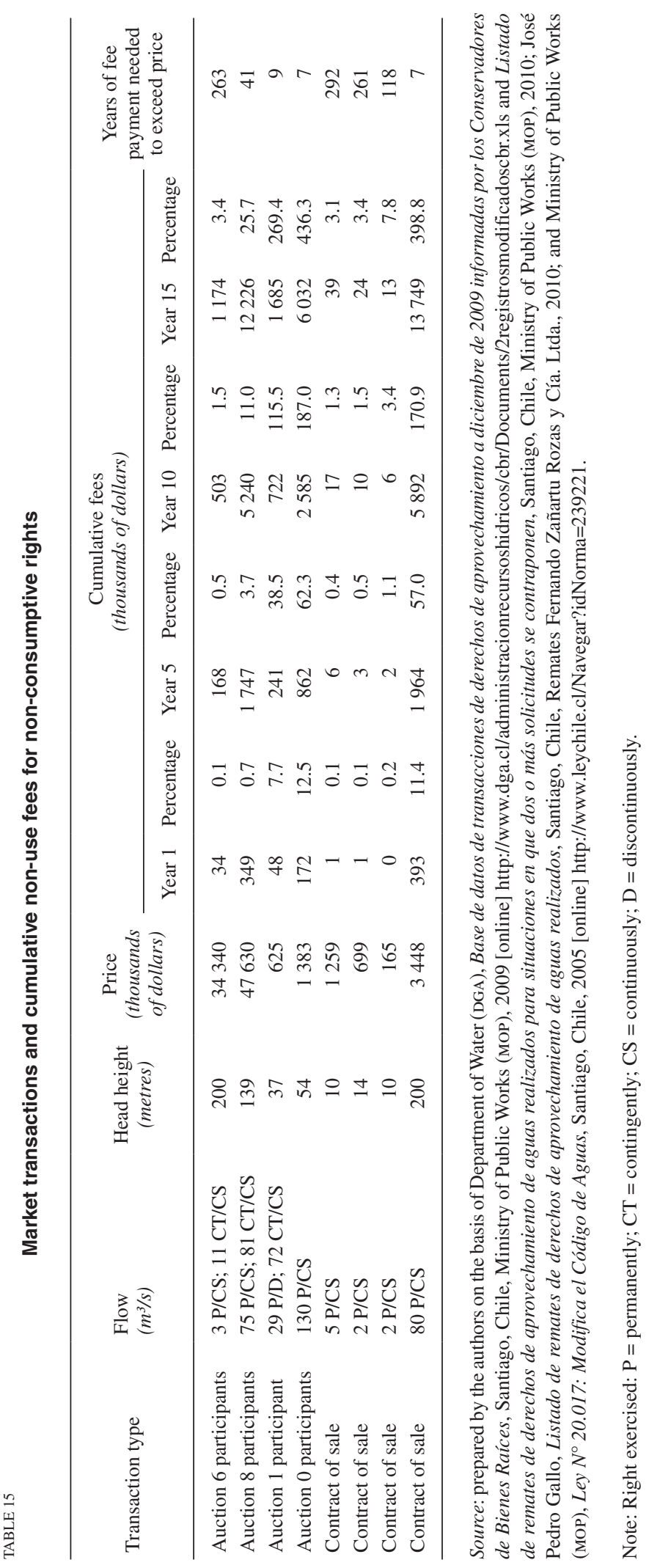


As the Introduction explains, the goal of the nonuse fee is not to raise revenue but to ensure that water is actually used. This means that in Chile the State prefers the owners of unused water rights to take up one of the following five options instead of paying the non-use fee: not pay the fee and lose the right at a public auction, or surrender, sell, rent or make effective use of the right (or, strictly, build extraction and return facilities as appropriate). It is reasonable to think that, with each year that passes, owners of unused water rights will be less willing to pay the fee than they were the year before. That said, something that is helpful for the analysis is to know the years in the fee charging process when owners ought to become more willing to take one of the five courses described in order to exit the list. Given the design of the non-use fee, these should be:

(i) the first year, as the owner might simply be unwilling to pay a fee;

(ii) the sixth, as it is the first year in which the value of the fee doubles, increasing the likelihood that the owner of an unused right will be unwilling to pay. Furthermore, where consumptive water rights are concerned, all fees paid are recovered if extraction facilities are built that year, which is not the case in the seventh, eighth and subsequent years, when fees paid during the first, second and subsequent years, respectively, will be forfeited for good if these facilities are constructed, since for rights of this type only fees paid in the previous five years are refunded once the facilities are built;

(iii) the ninth year for non-consumptive rights, as for this type of rights only payments made in the previous eight years are refunded once extraction and return facilities have been built; and

(iv) the eleventh year, as this is the first time the fee quadruples relative to the first year it is charged, once again increasing the likelihood that the owner of an unused water right will be unwilling to pay. Although these years mark milestones in the charging process that increase the incentive for the effective water use promoted by the non-use fee, it can be seen that the number of years of payment needed to exceed the average market price for consumptive rights (see table 14 ) is over 11 (the last year that represents a milestone in the charging process) in all regions, albeit with striking differences, which means that the fee cannot be expected to disincentivize ownership of unused consumptive rights in the short run. Nonetheless, as discussed earlier, some very substantial water rights have exited the list, which is a reason to think that the fee could improve its shortterm performance for rights of this type.
For non-consumptive water rights, by contrast, there are cases where the number of years of fee payment needed to exceed transaction prices is less than 11 , but there are others where it is a multiple of this, with centuries of payment sometimes being required to exceed the transaction price (see table 15). In the light of the early tendencies observed in the level of fee payment, these latter cases indicate that the non-use fee will not meet its objective in the short run where rights of this kind are concerned.

\section{Fee evasion mechanisms}

Fee evasion mechanisms have their origins in the very design of the non-use fee and in the original 1981 Water Code, which does not allow the work of promoting effective and beneficial use to be carried out by way of a straightforward correction that can be implemented via a non-use fee, this being in reality a fee for nonconstruction of facilities. There are two main mechanisms: non-registration of water rights with the property registry, and the building of facilities without effective use.

\section{(a) Non-registration of water rights with the property} registry (Conservador de Bienes Raíces-CBR)

There are cases in which it has not been possible to carry out auctions for non-payment of the fee because many rights are not duly registered with the CBR, making it legally impossible to conduct the auction (Vásquez, 2010). The number of water rights liable to the non-use fee that are not registered with the CBR is estimated at about 1,000 , or some $30 \%$ of all rights liable to the non-use fee in 2010 (Riestra, 2010). The impossibility of auctioning off a substantial portion of water rights stands in the way of the objectives the fee was meant to achieve, for while the Code makes CBR registration compulsory, it does not establish any penalties for non-registration (Riestra, 2009b) and, furthermore, it recognizes the existence of unregistered rights both in its article 181 and in its provisional article 2. This unresolved situation has led some specialists to suggest that there ought to be a property right guarantee involving an administrative process whereby rights expire or are extinguished or terminated if not registered with the CBR (Schulbach, 2010).

Perversely, rights that cannot be auctioned because they are not registered with the CBR have sometimes prevented rights that are registered from being auctioned, as some judges prefer to auction off the whole list of rights at once (Riestra, 2009b). 
(b) Construction of facilities without effective use

The State water authority knows of cases in which water extraction facilities have been built for consumptive rights with the sole object of avoiding fee payment, without any effective and beneficial use existing, a situation much like the one predicted by some authors before the 2005 reform to the 1981 Water Code was passed (Paredes and Gómez-Lobo, 2000; Domper, 2003).

It is actually easy to set up installations that simulate groundwater extraction, with rights owners installing diesel engines so that they can give inspectors an explanation for the lack of electricity at the time of the inspection while claiming that they are using the water, when in fact these are dummy installations set up only to avoid paying the fee (Proschle, 2010).

As regards surface water, Riestra (2010) states that cases of intakes leading nowhere have been discovered; since these works were approved by the Department of

\section{IV}

\section{Conclusions}

Following this analysis of the results of applying the non-use fee in its first four years, the conclusion is that the disincentive to ownership of water rights without effective use is still not working well, for several reasons. One is that all fee charging rounds have seen payment levels of over $67 \%$, and rising. Nonetheless, this could change if owners begin to make effective use of their rights, with the fees they have paid being refunded to them so that the take falls closer to zero. Furthermore, the effort to do away with hoarding and speculation looks weak in the initial stage because non-use fees would have to be paid for a number of years before the market price of water rights was exceeded, a consideration which suggests that fee payment percentages will remain high in the short run.

Another consideration is that, in practice, water is being kept available for the benefit of those who have the economic power to pay the fee and not exactly those who need the water and have plans for effective and beneficial use. This means that the competition for water use is favouring those who are in a position to delay their investments by paying the non-use fee, i.e., a subset of the universe of potential water users.
Water, no fee could be charged on them for the first two years (2007 and 2008). There is a Supreme Court ruling (2010) covering these groundwater situations, but the reinspection process is currently slow.

The kind of dummy installations described have not been detected in the case of non-consumptive rights. As predicted by Jara and Melo (2003), it is unlikely that superfluous works would be built to emulate the exercise of water rights of this kind, since they are subject to the regulatory oversight of the State in the case of hydroelectric installations. Furthermore, the extraction and return installations needed to exercise non-consumptive rights are usually much costlier than extraction facilities for the exercise of consumptive water rights.

Lastly, the operation of this fee evasion mechanism, which is almost exclusive to consumptive rights, could be one of the factors explaining why more rights of this type than non-consumptive rights have exited the fee payment list.
As for rights being surrendered, while there have been cases of this, they have been few (22) compared to the total number of water rights on the list, and only three have been substantial in terms of the fees they represent. The infrequency with which this happens may be due to the fact that the owners being charged would in theory be willing to accept any price higher than the non-use fee rather than just give up their rights, and indeed it is never in their interests to surrender a water right, as it will always be better to wait for it to be auctioned and then receive any surplus from the selling price.

Fees for consumptive rights present substantial geographical differences. The constants that were set to differentiate fees by macrozone within the country have proven to be insensitive to local realities, with equal treatment being given to basins that differ in their hydrological conditions and optimum use, the result being that owners' behaviour differs by latitude and, in consequence, that fees are giving better results within a single macrozone in regions where water rights are cheaper (or water is more abundant).

Again, fees are much less burdensome for nonconsumptive rights than for consumptive rights. This is 
demonstrated by the fact that fee payment percentages for the former have been in excess of $95 \%$ in all rounds. Furthermore, there is empirical evidence that rights of this type are drifting towards hydroelectric companies, which have no financial difficulty in paying the fee. While it might be thought that the unused water rights which still exist remain unused because they are valued by their respective owners and will soon be put to use, it is also possible to infer, particularly in the case of non-consumptive rights, that it may suit some groups to keep these rights unused in order to prevent new actors from moving into their markets and maintain oligopolies.

This suggests that the efficiency of the non-use fee is likely to improve over time in the case of consumptive rights, the fees for which have proved harder to afford than fees for non-consumptive rights.

The aim of favouring rational use of water resources is coming up against owners' fear of losing their water rights, an apprehension that in some cases has led to facilities being constructed purely to avoid paying the fee. This is an ambiguity that could be resolved by court rulings. Regarding non-registration of water rights with the CBR, the conclusion is that this is a severe enough problem to warrant legal amendments to the Water Code.

The path of "charging for non-use of water" that was taken in Chile is a remarkable one, an approach based on water abundance that contrasts with an international context where the scarcity approach predominates in the form of "charging for water use (or possession)". The fact that the path chosen is unusual makes ex post evaluation of the legislation particularly important since without it, in the absence of comparable international experience, future amendments to the law will only be justified once any undesirable effects have actually arisen.

It is relevant to ask if any politically feasible alternative to charging for non-use might have been better. The requirement of effective and beneficial use, a universal criterion in water regulations, was a better option than the non-use fee; however, the only direct method of applying it in Chile would be for unused water rights to be voided, and this was not politically feasible. Charging for use or ownership of water is not exactly an alternative to the non-use fee, but rather a compatible and complementary instrument; furthermore, it is a longterm initiative that is very hard to design and does not meet the core objective of the non-use fee (Comisión de Hacienda del Senado, 2000; Comisión de Obras Públicas del Senado, 2004, both cited by Valenzuela, 2009). Efforts to improve water legislation are controversial and are confined to the small sphere of action in which public policy can operate. This can be put down to the conflicts of interests in which water resources are embroiled, with disputes between the different actors often being a "dialogue of the deaf" that is not conducive to consensus. Again, among other reasons, what some consider to be errors in the legislation are a source of opportunity for others. Given this logic, establishing the non-use fee was an imaginative response to a problem that had no easy solutions (Valenzuela, 2009).

(i) A more obvious politically feasible alternative is to improve the non-use fee now that it has been established. Its design could be improved by applying it to basins and aquifers instead of political and administrative regions, thus avoiding situations in which changes in extraction points or the transfer of water rights from one region to another (i.e., when a water source straddles a boundary and is in two regions at once) lead to fees lower than those originally charged.

(ii) The value of the macrozonal constants used to calculate fees should be determined on the basis of the market price of water rights given that, under the methodologies originally employed, use was made of information from just one production sector per type of water right, namely sanitary service firms for consumptive rights (Peña, 1999, cited by Valenzuela, 2009) and hydroelectric firms for non-consumptive rights (CNE, 1997, cited by Valenzuela, 2009), which skewed the analysis and the subsequent calculation of the amounts to be charged.

(iii) The progressiveness of the non-use fee for nonconsumptive rights should be as originally proposed in the parliamentary debate, i.e., the fee should be multiplied by 5 in the sixth to tenth years and by 25 from the eleventh year onward, as the measure appears to have had little effect for rights of this kind.

(iv) The values of exempt flows should be applied as a discount to non-exempt flows. Under the present system, for example, a permanent, continuous consumptive right of $10.1 \mathrm{l} / \mathrm{s}$ in the north-centre macrozone is liable to the non-use fee, while a right with the same characteristics but a flow of $9.9 \mathrm{l} / \mathrm{s}$ is exempt.

(v) The calculation equation should include a flat amount to cover the administration costs to the State of applying the non-use fee, given that the inclusion of some rights on the lists entails large costs for the public sector relative to their importance for economic development.

(vi) Any water rights belonging to any State agency should be exempt from fee payment, but if they 
pass to a private owner then the arrears of fees for all the years in which the right was left unused should become payable by the State agency. This would prevent the State from charging itself fees when it held rights for strategic purposes and had no intention of transferring them, as with rights belonging to the Chilean army (military purposes) and the Municipality of Pucón (for the purposes of conservation to encourage tourism). Although the Water Code provides for such situations with its categories of reserve flows and ecological flows, it is on condition that these do not affect the rights of third parties, and they have to be approved by the President of the Republic. Furthermore, ecological flows are limited to a set amount.

(vii) Any right that is inalienable, and thus cannot be the object of speculation, should be exempted from fee payment, examples being those acquired in the name of indigenous communities through the Indigenous Land and Water Fund of the National Indigenous Development Corporation (CONADI). This is in consideration of the fact that if these fees are charged but not paid, the water rights associated with them can still not be auctioned or redistributed, so that it is arguably pointless to incur all the costs of these proceedings.

(viii)Rights subject to the non-use fee that are not registered with the Public Water Registry held by the
Department of Water should expire within a set time period following notification of this measure. This would prevent evasion of the non-use fee. Likewise, even leaving the matter of the fee aside, it would be advisable for any water rights not so registered to be liable to a fine unless the registration procedure is carried out within a set time; this would solve a recurrent problem with the Public Water Register, whose picture of water rights tends to be out of date. Lastly, it is worth considering whether the non-use fee has meant greater pressure on water resources. In theory it has, because the fee promotes water use, something that may be a problem in drier areas, where measures ought to aim at reducing extraction. In practice, however, what has happened to date is that fees on less abundant aquifers have usually been paid so that the pressure implied by the non-use fee has yet to be explicitly manifested, although this could change as time passes and fees progressively rise. The ideal outcome would be for organizations of users who take water from less abundant aquifers (which in many cases have yet to be formed) to take the steps necessary to meet two fee payment exemption conditions specially designed for situations of this type: alternation or proportional sharing of water rights, and the absence of circumstances, acts or agreements that prevent, restrict or hinder free competition in their area. Success in doing so will necessarily depend on the support and management capacity these organizations acquire.
Aylwin, Patricio (1992), "Mensaje de S.E. el Presidente de la República con el que inicia un proyecto de Ley que modifica el Código de Aguas", Mensaje, No. 283-325, Santiago, Chile [online] http:// sil.congreso.cl/cgi-bin/sil_abredocumentos.pl?1,308.

Barde, Jean Philippe and Nils Axel Braathen (2002), "Diseño y efectividad de los instrumentos fiscales relacionados con el medio ambiente en los países de la OCDE", Gaceta Ecológica, No. 63, Mexico City [online] http://redalyc.uaemex.mx/redalyc/ pdf/539/53906304.pdf.

CNE (National Energy Commission) (1997), "Informe de la Comisión Especial Legislativa encargada del estudio del régimen jurídico de las aguas sobre el proyecto de ley que modifica el Código de Aguas", Boletín, No. 876-09, Valparaiso, Chile, 18 March [online] http://sil.congreso.cl.

Comisión de Hacienda del Senado (2004), "Segundo informe de la Comisión de Hacienda, recaído en el proyecto de ley, en segundo trámite constitucional, que modifica el Código de Aguas", Boletín, No. 876-09, Valparaiso, Chile, National Congress [online] http:// sil.congreso.cl/cgi-bin/sil_abredocumentos.pl?2,7105.

(2000), "Informe de la Comisión de Hacienda, recaído en el proyecto de ley de la H. Cámara de Diputados que modifica el Código de Aguas", Boletín, No. 876-09, Valparaiso, Chile, 15 September [online] http://sil.congreso.cl.
Comisión de Obras Públicas del Senado (2004), "Segundo informe de la Comisión de Hacienda, recaído en el proyecto de Ley, en segundo trámite constitucional, que modifica el Código de Aguas", Boletín, No. 876-09, Valparaiso, Chile, National Congress [online] http://sil.congreso.cl/cgi-bin/sil_abredocumentos.pl?2,7105.

Comisión Especial sobre Régimen Jurídico de las Aguas (1997), "Informe de la Comisión Especial Legislativa encargada del estudio del régimen jurídico de las aguas sobre el proyecto de Ley que modifica el Código de Aguas", Boletín, No. 876-09, Valparaiso, Chile, National Congress [online] http://sil.congreso. cl/cgi-bin/sil_abredocumentos.pl?2,8792.

Comisión Preventiva Central (1996), "Dictamen de la Comisión ante consulta del Sr. Ministro Presidente de la Comisión Nacional de Energía”, C.P.C. No. 992/636, Santiago, Chile, Fiscalía Nacional Económica [online] http://mailweb.fne.gob.cl/db/ jurispru.nsf/916bbd5360412187842573\%203e005e4291/2b2 8b1f6d94c0fb408256e1c000a27de/\$FILE/Doc0047.pdf.

DGA (Department of Water) (2010a), Bases de datos del listado de derechos de aprovechamiento de aguas afectos a pago de patente por no uso, procesos 2007 a 2010, Santiago, Chile, Ministry of Public Works.

(2010b), Listado de remates de derechos de aprovechamiento de aguas realizados para situaciones en que dos o más solicitudes se contraponen, Santiago, Chile, Ministry of Public Works. 
(2010c), Informe sobre patente por no uso de derechos de aprovechamiento de aguas, Santiago, Chile, Ministry of Public Works.

(2010d), Informe de la elaboración del listado de derechos de aprovechamiento de aguas afectos a pago de patente por no uso, proceso 2010, Santiago, Chile, Ministry of Public Works. (2009), Base de datos de transacciones de derechos de aprovechamiento a diciembre de 2009 informadas por los Conservadores de Bienes Raíces, Santiago, Chile, Ministry of Public Works [online] http://www.dga.cl/ administracionrecursoshidricos/cbr/Documents/2registrosmo dificadoscbr.xls.

Domper, María de la Luz (2003), "La eficiencia en el mercado de derechos de agua: ¿Patente por no-uso o por tenencia?”, Serie Informe Económico, No. 141, Santiago, Chile, Instituto Libertad y Desarrollo [online] http://www.libertadydesarrollo.cl/biblioteca/ serie/Economico/141_serie_informe_economico.pdf.

Dourojeanni, Axel and Andrei Jouravlev (1999), "El Código de Aguas de Chile: Entre la ideología y la realidad", Recursos naturales e infraestructura series, No. 3 (LC/L.1263-P), Santiago, Chile, Economic Commission for Latin America and the Caribbean (ECLAC). United Nations publication, Sales No. S.99.II.G.43 [online] http://www.eclac.org/publicaciones/xml/5/4465/ lc11263.pdf.

ECLAC (Economic Commission for Latin America and the Caribbean) (1995), "Mercados de derechos de agua: Entorno legal" (LC/R.1485), Santiago, Chile [online] http://www.eclac.org/ publicaciones/xml/0/5670/Lcr1485e.pdf.

Gallo, José Pedro (2010), Listado de remates de derechos de aprovechamiento de aguas realizados, Santiago, Chile, Remates Fernando Zañartu Rozas y Cia. Ltda.

Jara, Esteban and Oscar Melo (2003), "Patentes de no uso de derechos de aprovechamiento en la reforma al Código de Aguas: ¿Se justifica su implementación?", VIII Congreso de Economistas Agrarios. Pensando la agricultura del 2010: Desafíos, ajustes y política, Santiago, Chile, Catholic University of Chile [online] http://www. aeachile.cl/docs/congresos/resumen_viii_congreso_2003.pdf.

Jouravlev, Andrei (2000), "Avances en la modernización de los sistemas de gestión del agua en América Latina y el Caribe", paper presented at the Seminar "Gestión de agua: Experiencia de América Latina", Lima, National Development Institute (INADE)/Food and Agriculture Organization of the United Nations (FAO) [online] http://infoagro.net/shared/docs/a2/Gestion-delAgua/12-A3B3-ALC.pdf.

Ministry of Justice (1981), Decreto con Fuerza de Ley $N^{o} 1122$ : Fija texto del Código de Aguas, Santiago, Chile [online] http://www. leychile.cl/Navegar?idNorma $=5605$.

MOP (Ministry of Public Works) (2005), Ley $N^{o} 20.017$ : Modifica el Código de Aguas, Santiago, Chile [online] http://www.leychile. $\mathrm{cl} /$ Navegar?idNorma $=239221$.

Paredes, Ricardo and Andrés Gómez-Lobo (2000), Reflexiones sobre el proyecto de modificación del Código de Aguas, Santiago, Chile, University of Chile /Faculty of Economic and Administrative Sciences [online] http://www.uchile.cl/pde/Noticias/aguas.pdf.

Peña, Humberto (2009), private communication, Santiago, Chile. (2003), "Incluso si es reformado, nuestro Código de Aguas será el más liberal del mundo", Revista Chileriego, No. 14, Santiago, Chile.

Proschle, Juan Carlos (2010), private communication, Valparaiso, Chile. Riestra, Francisco (2010), private communication, Santiago, Chile. (2009a), "Fiscalización de cauces naturales y uso del agua", Revista Skretting Informa, No. 12, Santiago, Chile [online] http://www.skretting.cl/Internet/SkrettingChile/webInternet. nsf/wprid/4D129EE722677EF284257590005D78C0/\%24fi le/Rev11CAD.pdf.

(2009b), "Private communication", Santiago, Chile.

Schulbach, Ernesto (2010), private communication, Santiago, Chile. Supreme Court (2010), "Pronunciamiento en autos caratulados "Hidroeléctrica Guardia Vieja S.A. con Dirección General de Aguas", Rol de Corte, No. 5083-2008, Santiago, Chile, Judicial Power.

Valenzuela, Christian (2009), La patente por la no-utilización de las aguas en Chile: origen, diseño y primeras experiencias en su implementación, Santiago, Chile, University of Chile/Faculty of Agricultural Sciences [online] http://www.cepal.org/drni/ noticias/documentosdetrabajo/0/39270/Christian_Valenzuela.pdf.

Vásquez, Álvaro (2010), private communication, Santiago, Chile. 